\title{
The Biological Activity Research of the Nano-Drugs Based on 5-Fluorouracil-Modified Quantum Dots
}

This article was published in the following Dove Press journal: International Journal of Nanomedicine

\section{Lu-Lu Qiao \\ Wen-Jing Yao \\ Zhi-Qiang Zhang \\ Xiaojing Yang \\ Mei-Xia Zhao (ID}

Key Laboratory of Natural Medicine and Immune Engineering of Henan Province, Henan University, Kaifeng 475004, People's Republic of China
Correspondence: Mei-Xia Zhao

Key Laboratory of Natural Medicine and Immune Engineering of Henan Province, Henan University, Jinming Road, Kaifeng 475004, People's Republic of China Email zhaomeixia20II@henu.edu.cn
Purpose: Over the past decades, quantum dots (QDs) have shown the broad application in diverse fields, especially in intracellular probing and drug delivery, due to their high fluorescence intensity, long fluorescence lifetime, strong light-resistant bleaching ability, and strong light stability. Therefore, we explore a kind of therapeutic potential against cancer with fluorescent imaging.

Methods: In the current study, a new type of QDs (QDs@L-Cys-TAEA-5-FUA) capped with L-cysteine (L-Cys) and tris(2-aminoethyl)amine (TAEA) ligands, and conjugated with 5-fluorouracil-1-acetic acid (5-FUA) has been synthesized. Ligands were characterized by electrospray ionization mass spectrometry and $\mathrm{H}$-nuclear magnetic resonance $\left({ }^{1} \mathrm{H} \mathrm{NMR}\right)$ spectroscopy. The modified QDs were characterized by transmission electron microscopy, ultraviolet and visible spectrophotometry (UV-Vis), and fluorescence microscopy. And the biological activity of modified QDs was explored by using MTT assay with HeLa, SMMC7721 HepG2, and QSG-7701 cells. The fluorescence imaging of modified QDs was obtained by fluorescence microscope.

Results: The modified QDs are of controllable sizes in the range of 4-5 $\mathrm{nm}$ and they possess strong optical emission properties. UV-Vis and fluorescence spectra demonstrated that the L-Cys-TAEA-5-FUA was successfully incorporated into QD nanoparticles. The MTT results demonstrated that L-Cys-TAEA-5-FUA modified QDs could efficiently inhibit the proliferation of cancer cells as compared to the normal cells, illustrating their antitumor efficacy. The mechanistic studies revealed that the effective internalization of modified QDs inside cancer cells could inhibit their proliferation, through excessive production of intracellular reactive oxygen species, leading to apoptosis process.

Conclusion: The present study suggests that modified QDs can enter cells efficiently and could be employed as therapeutic agents for the treatment of various types of cancers with fluorescent imaging.

Keywords: quantum dots, 5-fluorouracil, nano-drugs, apoptosis, antitumor activity

\section{Introduction}

Quantum dots (QDs)-based nanomaterials have special photochemistry properties due to their unique electrochemical and photophysical properties, facilitating the wide applications of QDs, especially as nano-fluorescent probes and antitumor drug carriers. ${ }^{1-5}$ Although issues regarding the cytotoxicity of QDs have been raised, the surface of QDs can be modified to reduce their toxicity towards cells, while improving their water solubility and tumor cell targeting ability. ${ }^{1,6-9}$ The researchers have employed various biological molecules including peptides, antibodies, proteins, and 
DNA to coat the surface of QDs, and these modified QDs have intensely been studied as a new class of nanoparticle probe and drug carrier in diverse biomedical research areas, ranging from cellular fluorescence imaging and diagnostics in biomedicine to environmental monitoring for public health and security. ${ }^{10-15}$ However, the major hurdle for in vivo applications of QDs based nanomaterials is their organellespecific targeted delivery.

Amino acids, containing amino and carboxyl groups, are the basic components of protein. ${ }^{16,17}$ Since amino acids are mostly water-soluble and inexpensive, they have frequently been used as capping agents for QDs. ${ }^{18-21}$ The amino acids are often linked to the surface of QDs, followed by attachment of other drugs with antitumor activity and the biomolecule with tumor cells targeting ability to form targeted drug delivery systems. $^{22-24}$ 5-Fluorouracil (5-FU) is an antimetabolite and a constituent of RNA. ${ }^{25-28}$ Following intracellular conversion to fluorouracil deoxynucleotide, 5-FU can inhibit the DNA synthesis via blocking the conversion of deoxyribonucleate to thymidylic acid by intracellular thymidylic acid synthase. ${ }^{29,30}$ Moreover, 5-FU can be incorporated into RNA and it can interfere with the protein synthesis after conversion to 5-Fluorouridine in vivo. ${ }^{31,32} 5$-FU also inhibits the activity of exosome complexes (an exonuclease). Furthermore, it is a potent anti-cancer drug that can be used to treat a number of cancers including gastric, colon, lung, and breast cancers. ${ }^{33-36}$ However, the water solubility of 5-FU is very poor and intravenous administration of this drug is associated with the toxicity in bone marrow and gastrointestinal tract. ${ }^{37-39}$ To address the limitations related to the administration of 5-FU, the use of QDs was investigated to aide its pharmacological actions. $^{40-44}$ To date, a few studies on L-cysteine and 5-FU-modified QDs have been reported.

In the present study, we synthesized a new type of QDs with controllable sizes (4-5 nm) and strong optical emission properties. In this nanoplatform, QDs were coated with the ligands L-Cys- and TAEA-, followed by conjugation of 5-FUA. The biological activity of the modified QDs was checked in different types of cells (HeLa, QSG-7701, SMMC-7721, and HepG2 cells) through cell viability assay using MTT reagent. The results demonstrated that L-Cys-TAEA-5-FUA-modified QDs effectively inhibited the proliferation of cancerous cells when compared to the normal cells. The cell morphology analysis, flow cytometry (using annexin
V-FITC), and fluorescence microscopy (AO/EB staining, mitochondrial membrane potential (MMP), and reactive oxygen species (ROS) determination) further reveal that the modified QDs could induce apoptosis to cancer cells through the formation of excessive intracellular ROS. Overall, the L-Cys-TAEA-5-FUA-modified QDs were found to enter intracellular and can be as potent antitumor agents for the treatment of cancers via apoptosis.

\section{Materials and Methods \\ Materials}

All the reagents were purchased from commercial suppliers and used without further purification. Solvents used were purified by standard methods prior to use. Cervical cancer cells (HeLa), human normal hepatocytes (QSG7701), and human hepatoma cells (SMMC-7721 and HepG2) were procured from Shanghai Cell Bank of Chinese Academy of Sciences.

${ }^{1} \mathrm{H}$ NMR spectra were recorded on a Bruker AV-400 spectrometer. UV-Vis spectra were monitored with a Varian Cary 300 BIO UV-Vis spectrophotometer. Fluorescence spectra were measured by using a Varian Cary Eclipse fluorescence Spectrophotometer (American, Agilent, Co.). Fluorescence images were obtained employing a fluorescence microscope (Leica, Germany). The cell fluorescence intensity was recorded by using a FACSCalibur flow cytometer (Becton Dickinson \& Co., Franklin Lakes, NJ).

\section{Synthesis of L-Cys-TAEA (Scheme I)}

Tris(2-aminoethyl)amine (TAEA) (2.0 g, $13.7 \mathrm{mmol})$ dissolved in $70 \mathrm{~mL}$ of dichloromethane was taken in a round-bottomed flask equipped with a magnetic stirring bar. Then, (Boc) ${ }_{2} \mathrm{O}$ (1.0 g, $\left.4.6 \mathrm{mmol}\right)$ dissolved in dichloromethane was slowly added dropwise to the flask using a constant pressure funnel for $1 \mathrm{~h}$ at $0^{\circ} \mathrm{C}$, followed by stirring at room temperature overnight. The resulting reaction mixture was evaporated to dryness under reduced pressure, and the residue was extracted using ethyl acetate and distilled water. Removal of the solvent in the organic phase resulted in a solid material. After drying under vacuum, the solid material was purified by silica gel column chromatography using a $\mathrm{CH}_{2} \mathrm{Cl}_{2}: \mathrm{CH}_{3} \mathrm{OH}(\mathrm{v}: \mathrm{v}=50: 1)$ mixture as the eluent to obtain the colorless grease protected TAEA.

Compound 1 ( $2.0 \mathrm{~g}, 3.5 \mathrm{mmol}$ ) in $100 \mathrm{~mL}$ of acetonitrile and NHS $(0.59 \mathrm{~g}, 3.5 \mathrm{mmol})$ were taken in a $250 \mathrm{~mL}$ roundbottomed flask, placed on a magnetic stirrer. EDC (0.89 g, 3.5 mmol) was then added into the flask under ice-cooling 
<smiles>CC(C)(C)OC(=O)NCCN(CCN)CCNC(=O)OCC(C)(C)OC(C)(C)C</smiles>

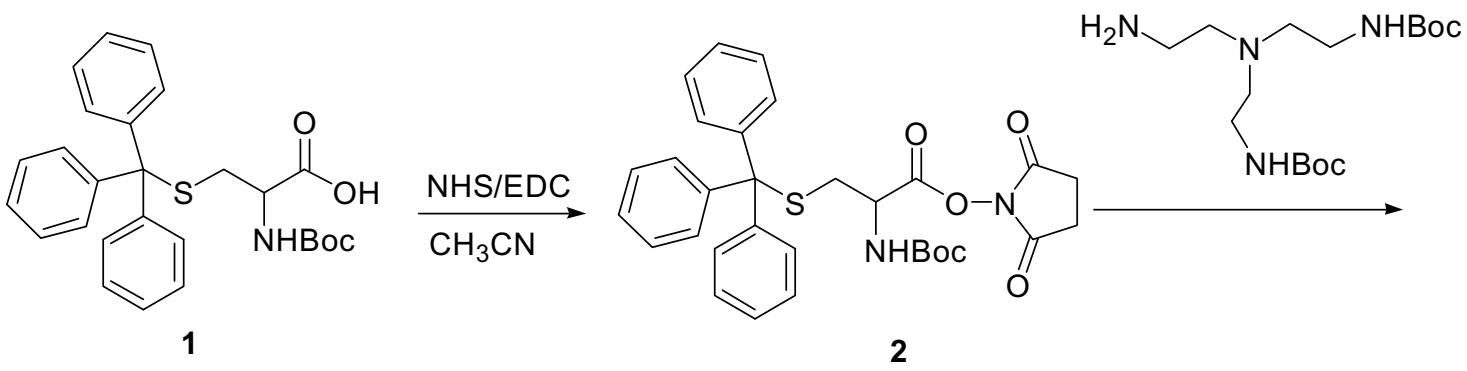<smiles>CC(C)(C)OC(=O)NCCN(CCNC(=O)OC(C)(C)C)CCNC(=O)C(N)CSC(c1ccccc1)(c1ccccc1)c1ccccc1</smiles>

Scheme I Schematic illustration for the synthesis of L-Cys-TAEA.

condition, followed by stirring for $2 \mathrm{~h}$ at $0^{\circ} \mathrm{C}$. The reaction mixture was then further stirred under $\mathrm{N}_{2}$ at room temperature overnight. The resulting precipitate was filtered and extracted with dichloromethane and distilled water. Removal of solvent from the organic phase resulted in a white foamy solid 2.

Protected TAEA ( $0.5 \mathrm{~g}, 1.5 \mathrm{mmol})$, compound $2(0.84 \mathrm{~g}$, $1.5 \mathrm{mmol})$, and $\mathrm{NaHCO}_{3}(0.15 \mathrm{~g}, 1.8 \mathrm{mmol})$ were added to a $100 \mathrm{~mL}$ round-bottomed flask and the mixture was stirred for $12 \mathrm{~h}$ at $60^{\circ} \mathrm{C}$. The reaction mixture was evaporated to dryness under reduced pressure, and the residue was extracted using dichloromethane and distilled water. Removal of the solvent from the organic phase resulted in a solid material. After vacuum drying, the solid material was purified by silica gel column chromatography with a $\mathrm{CH}_{2} \mathrm{Cl}_{2}: \mathrm{CH}_{3} \mathrm{OH}(\mathrm{v}: \mathrm{v}=10: 1)$ mixture as the eluent to obtain the yellow oil compound 3 .

Compound 3 was dissolved in $10 \mathrm{~mL} \mathrm{CH}_{2} \mathrm{Cl}_{2}$ in a $50 \mathrm{~mL}$ round-bottom flask and placed under $\mathrm{N}_{2}$ vacuum at $0^{\circ} \mathrm{C}$. Next, trifluoroacetic acid $(9.5 \mathrm{~mL})$ and triethylsilane $(0.5 \mathrm{~mL})$ were added to the flask, followed by stirring at $25^{\circ} \mathrm{C}$ for $6 \mathrm{~h}$. The reaction mixture was evaporated to dryness under reduced pressure and residue was extracted with methylene chloride and distilled water. Evaporation of solvent in the aqueous phase resulted in L-Cys-TAEA.

1. Cys-TAEA, yield: $60 \%$; ${ }^{1} \mathrm{H}$ NMR $(300 \mathrm{MHz}$, deuterium oxide) $\delta 4.10(\mathrm{t}, \mathrm{J}=6.0 \mathrm{~Hz}, 1 \mathrm{H}), 3.40(\mathrm{t}, \mathrm{J}=7.5$ $\mathrm{Hz}, 2 \mathrm{H}), 3.14(\mathrm{t}, \mathrm{J}=6.0 \mathrm{~Hz}, 4 \mathrm{H}), 3.00(\mathrm{t}, \mathrm{J}=7.5 \mathrm{~Hz}$, $6 \mathrm{H}), 2.85(\mathrm{t}, \mathrm{J}=7.5 \mathrm{~Hz}, 2 \mathrm{H}) .{ }^{13} \mathrm{C} \mathrm{NMR}\left(75 \mathrm{MHz}, \mathrm{D}_{2}\right.$ O) $\delta 170.06,163.55,163.07,162.60,162.13,122.00$, $118.14,114.27,110.41,54.31,49.75,36.22,29.68$, 23.77. ESI-MS, m/z: $250.15[\mathrm{M}+\mathrm{H}]^{+}$.

\section{Synthesis of QDs}

$\mathrm{CdSe}, \mathrm{CdSe} / \mathrm{CdS}$, and $\mathrm{CdSe} / \mathrm{ZnS}$ QDs capped with trin-trioctylphosphine oxide (TOPO) were synthesized employing organometallic procedures as described in our previous report. ${ }^{45}$ The QDs synthesized using this procedure exhibit high crystallinity, narrow emission spectra, and narrow size distributions.

\section{Synthesis of Water-Soluble L-Cys-TAEA- Modified QDs}

One-milliliter QDs (CdSe or $\mathrm{CdSe} / \mathrm{ZnS}$ or $\mathrm{CdSe} / \mathrm{CdS}$ ) in $1 \mathrm{~mL}$ of chloroform, L-Cys-TAEA $(300 \mathrm{mg})$ in $3 \mathrm{~mL}$ of 


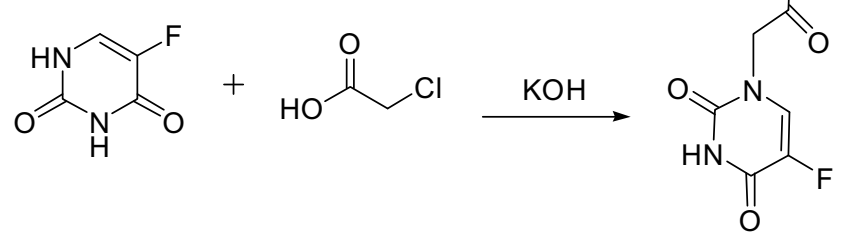

Scheme 2 Schematic illustration for the synthesis of 5-FUA.

triple distilled water, and 10 drops of triethanolamine were placed in a bottle and sonicated for $4 \mathrm{~h}$. The reaction was considered complete when red QDs from the lower organic phase diffused into the upper aqueous phase. Ethyl acetate was then added to precipitate nanocrystal complexes and the nanocrystals were purified from side products and unreacted precursors. The solid was filtered from the solution and dried under vacuum to generate three water-soluble QDs, namely, CdSe@L-Cys-TAEA, CdSe/ZnS@L-Cys-TAEA, and CdSe/ CdS@L-Cys-TAEA.

\section{Synthesis of 5-FUA (Scheme 2)}

$5-\mathrm{FU}(2.6 \mathrm{~g}, 20 \mathrm{mmol})$ and $\mathrm{KOH}(2.24 \mathrm{~g}, 40 \mathrm{mmol})$ in $16 \mathrm{~mL}$ of water and chloroacetic acid $(3.4 \mathrm{~mL}, 36 \mathrm{mmol})$ in $8 \mathrm{~mL}$ of water were placed in a vessel. The solution mixture was stirred at room temperature for $30 \mathrm{~min}$. Then, the $\mathrm{pH}$ of the reaction was adjusted to 10 with a $10 \% \mathrm{KOH}$ solution and the reaction was refluxed for $2 \mathrm{~h}$. After cooling the reaction liquid, the $\mathrm{pH}$ of the reaction mixture was adjusted to 2 with concentrated hydrochloric acid. Then, the reaction mixture was evaporated under reduced pressure, and a small amount of water was added to dissolve the solid. Then, the solution was placed in ice bath to yield the precipitation, which was filtered to obtain the solid 5-Fluorouracil-1-acetic acid (5-FUA).

5-FUA, yield: 82\%; ${ }^{1} \mathrm{H}$ NMR (300 MHz, DMSO-d6) $\delta$ 11.94 (d, J=3.0 Hz, 1 H), 8.08 (d, J=4.5 Hz, 1 H), 4.36 (s, 2 H).

\section{Synthesis of QDs@L-Cys-TAEA-5-FUA}

5-FUA (109 mg, $0.58 \mathrm{mmol})$ in $2 \mathrm{~mL}$ of DMSO, EDC (111 mg, $0.58 \mathrm{mmol})$, NHS (66.7 mg, $0.58 \mathrm{mmol}$ ), and the above prepared QDs@L-Cys-TAEA were taken in a $50-\mathrm{mL}$ round-bottomed flask, placed on a magnetic stirrer. The solution was stirred constantly at room temperature for $4 \mathrm{~h}$. After completion of the reaction, the precipitate was centrifuged and washed by DMSO and $\mathrm{C}_{2} \mathrm{H}_{5} \mathrm{OH}$ to obtain three target products CdSe@L-Cys-TAEA-5-FUA, CdSe/ZnS@L-CysTAEA-5-FU, and CdSe/CdS@L-Cys-TAEA-5-FUA.

\section{Cell Culture}

HeLa, QSG-7701, SMMC-7721, and HepG2 cells were cultured in RMPI-1640 medium and maintained at $37^{\circ} \mathrm{C}$ incubator with $5 \% \mathrm{CO}_{2}$. Cells were allowed to grow in a monolayer in the tissue culture flask.

\section{Cell Viability Assays}

The antitumor ability of the modified QDs was investigated in HeLa, QSG-7701, SMMC-7721, and HepG2 cells using a modified cell viability assay using 3-(4,5-dimethyl2-thiazolyl)-2,5-diphenyltetrazolium bromide (MTT) method. Briefly, cells were seeded into 96-well plates at $5 \times 10^{4}$ cells per well. After $12 \mathrm{~h}$, the cells were incubated with the samples (modified QDs: 50, 100, 200, 500, and $1000 \mu \mathrm{g} / \mathrm{mL}$, original QDs: 5, 10, 20, 50, $100 \mu \mathrm{g} / \mathrm{mL}$ ) for $48 \mathrm{~h}$. Then, $20 \mu \mathrm{L}$ MTT $(2.5 \mathrm{mg} / \mathrm{mL})$ was added to each well. After $4 \mathrm{~h}$ incubation, the medium was removed and $100 \mathrm{~mL}$ DMSO was added to each well of the plates to dissolve the formazan products. Absorbance of the solution in each well was read at $570 \mathrm{~nm}$ using a Tecan Infinite F200 M200 multimode reader. The inhibition rate was calculated from plotted results considering the untreated cells as $100 \%$.
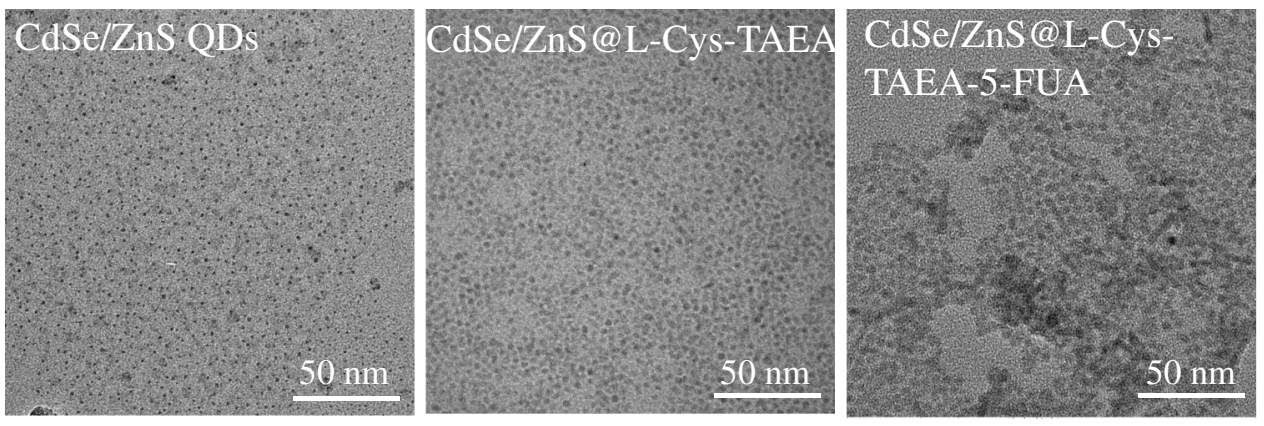

Figure I Representative TEM images of CdSe/ZnS QDs, CdSe/ZnS@L-Cys-TAEA, and CdSe/ZnS@L-Cys-TAEA-5-FUA. Scale bars = 50 nm. 


\section{Hoechst Staining Study for the Detection of Apoptosis}

Cells were seeded in 6-well plates and allowed to adhere for overnight. Then, the cells were incubated with $\mathrm{CdSe} /$ ZnS@L-Cys-TAEA-5-FUA (200, 100, 50, 20, and $10 \mu \mathrm{g} /$ $\mathrm{mL}$ ) for respective time points and stained with Hoechst $33342(10 \mathrm{mg} / \mathrm{mL})$ at $37^{\circ} \mathrm{C}$ for $30 \mathrm{~min}$. The fluorescence images of cells were captured using a fluorescence microscope. The rate of the abnormal (condensed or fragmented) nucleus was obtained by counting eight randomly chosen fields per dish for each experimental group from three independent experiments and expressed as percent apoptotic nuclei. Cell nuclei stained with Hoechst 33342 were observed at a wavelength of $405 \mathrm{~nm}$ and emission wavelength between 430 and $480 \mathrm{~nm}$.

\section{Apoptosis Assay Using Annexin V-FITC Staining by Flow Cytometry}

Apoptosis assay was carried out using an annexin V-FITC apoptosis detection kit by a FACSCalibur flow cytometer. Briefly, cells were seeded in 6-well plates for $24 \mathrm{~h}$. The cells were incubated with the treatments $(30,100 \mu \mathrm{g} / \mathrm{mL})$ for $6 \mathrm{~h}$. The cells were then carefully washed with PBS and resuspended in PBS buffer. After that, the cells were incubated with annexin V-FITC for $30 \mathrm{~min}$ at $37^{\circ} \mathrm{C}$, followed by flow cytometry analysis. Data were analyzed using the BD Cell Quest software. Percentage of live and apoptotic cells was determined using negative controls, prepared by staining control experiments with propidium iodide (PI) or annexin V.
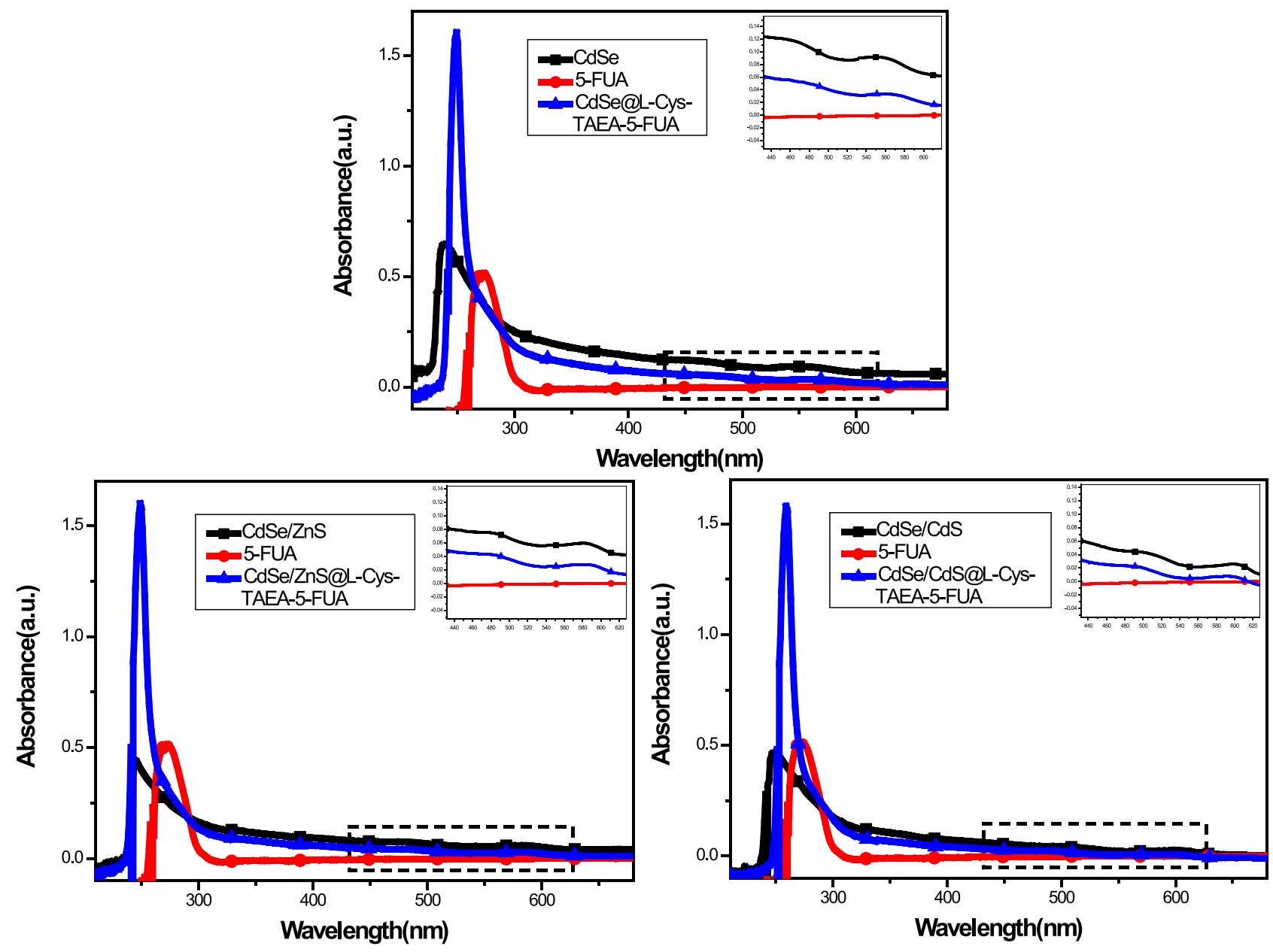

Figure 2 UV-Vis spectra of the original QDs, 5-FUA, and QDs@L-Cys-TAEA-5-FUA. 


\section{AO/EB Staining Study for Determination of Apoptosis}

Cellular apoptosis was evaluated using the AO/EB apoptosis detection kit employing fluorescence microscopy. HeLa cells were first seeded in 6-well plates for 24 h. The cells were then incubated with the samples $(30$, $100 \mu \mathrm{g} / \mathrm{mL}$ ) for $6 \mathrm{~h}$. The cells were then thoroughly washed with $\mathrm{PBS}$, followed by incubation with $\mathrm{AO} / \mathrm{EB}$ for $30 \mathrm{~min}$ at $37^{\circ} \mathrm{C}$. The fluorescence images of the cells were captured using a fluorescence microscope.

\section{Analysis of Mitochondrial Membrane Potential (MMP)}

MMP of cancer cells in presence of the QDs was assessed using flow cytometry. In brief, HeLa cells were first incubated with the samples for $24 \mathrm{~h}$. The cells were then collected via trypsinization and incubated in media containing $10 \mu \mathrm{g} / \mathrm{mL}$ JC-1 dye $\left(5,5^{\prime}, 6,6^{\prime}\right.$-tetrachloro-1, $1^{\prime}, 3,3^{\prime}$ - tetraethyl-imidacarbocyanine iodide; Molecular Probes) for $15 \mathrm{~min}$ at $37^{\circ} \mathrm{C}$. After that, the cells were carefully washed with PBS and the MMP of cells was measured using a FACSCalibur flow cytometer. Photomultiplier settings were adjusted to detect JC-1 monomer fluorescence signals using an FL1 detector (green fluorescence, centered around $530 \mathrm{~nm}$ ), and $\mathrm{JC}-1$ aggregate fluorescence signals employing FL2 detector (red fluorescence, centered around $590 \mathrm{~nm}$ ). Ten thousand events were acquired for each sample, and the red and green mean fluorescence intensities were analyzed using BD Cell Quest software.

To evaluate the MMP through fluorescence microscope, HeLa cells were seeded in 6-well plates and incubated $5 \mu \mathrm{g} /$ $\mathrm{mL} \mathrm{Rh} 123$ in complete media for $30 \mathrm{~min}$ at $37^{\circ} \mathrm{C}$. The cells were then washed twice with PBS and the MMP was observed using a fluorescence microscope.

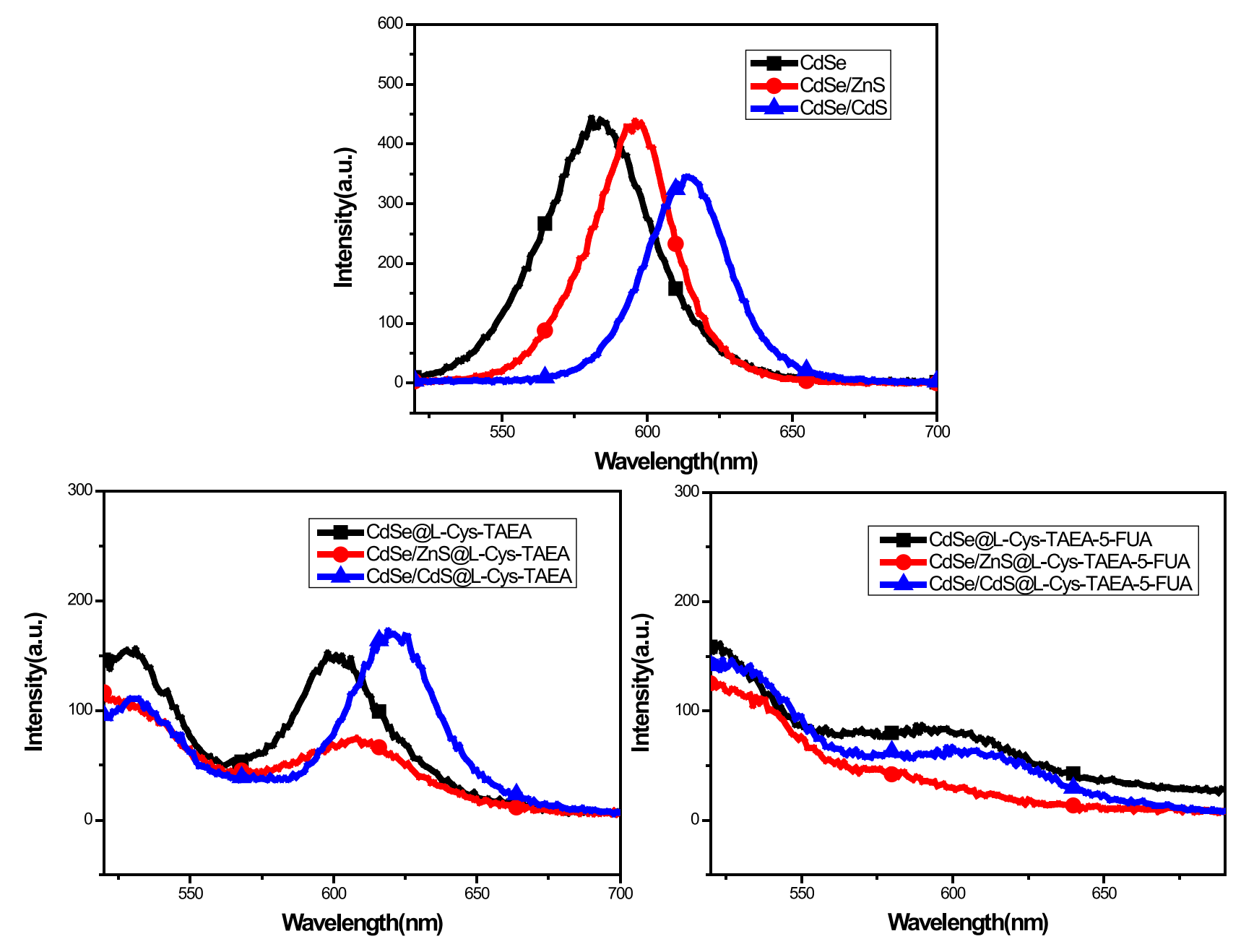

Figure 3 Fluorescence spectra of the original QDs, QDs@L-Cys-TAEA, and QDs@L-Cys-TAEA-5-FUA. 


\section{Determination of Reactive Oxygen Species (ROS)}

Cellular accumulation of ROS was determined using the 2',7'-dichlorodihydrofluorescein diacetate $\left(\mathrm{H}_{2} \mathrm{DCF}-\mathrm{DA}\right)$ reagent. Briefly, after treatment with samples for $12 \mathrm{~h}$, the cells were rinsed thrice with PBS to remove the unbound samples. The cells were then incubated with 10 $\mu \mathrm{M}$ of $\mathrm{H}_{2} \mathrm{DCF}-\mathrm{DA}$ for $30 \mathrm{~min}$ at $37^{\circ} \mathrm{C}$. Next, the wells were washed twice with PBS to remove the excess dye. The fluorescence intensity of the cells was determined using a FACSCalibur flow cytometer and fluorescence microscope.

\section{Results and Discussion \\ Synthesis and Characterizations}

In the present study, three different kinds of QDs (CdSe, $\mathrm{CdSe} / \mathrm{ZnS}$, and $\mathrm{CdSe} / \mathrm{CdS}$ ) were prepared by organic phase synthesis method. These QDs were characterized by various physicochemical techniques including TEM, UV-Vis, and fluorescence spectroscopy (Figures 1-3). The QDs exhibited high fluorescence intensity, narrow emission spectra, as well as narrow size distributions. Besides the QDs, the ligands L-cysteine-tris(2-aminoethyl)amine (L-Cys-TAEA) and 5-FUA were also synthesized and characterized by ESI-MS, ${ }^{1} \mathrm{H}$ NMR spectroscopy, or ${ }^{13} \mathrm{C}$ NMR spectroscopy. At first, the surface of QDs was modified with L-Cys-TAEA. However, the cell growth inhibition rate of the QDs@L-CysTAEA is found to be lower. Therefore, 5-FUA was further conjugated with the QDs@L-Cys-TAEA to improve the cell growth inhibition rate. The size and morphology of the original QDs, QDs@L-Cys-TAEA, and QDs@L-Cys-TAEA -5-FUA were then characterized using TEM. As shown in Figure 1, the modified QDs maintained the good dispersion and uniformity with spherical shape in PBS. The modified QDs showed good water solubility and dispersibility.

The modified QDs also exhibited better optical properties in UV-Vis spectra and fluorescence spectroscopy. Figure 2 depicts the absorption spectra of original QDs, 5-FUA, and the modified QDs. It can be observed that with the addition of 5-FUA, the UV-Vis absorption spectrum of QDs@L-Cys-TAEA-5-FUA exhibits a new absorption band at around $270 \mathrm{~nm}$, which could be attributed to the absorption of 5-FUA. Moreover, there was no much difference in the position or the width of absorbance bands between QDs@L-Cys-TAEA-5-FUA and original QDs, suggesting that 5-FUA was successfully incorporated into QDs.
The original QDs, QDs@L-Cys-TAEA, and QDs@L-Cys-TAEA-5-FUA were further characterized by fluorescence spectroscopy. As shown in Figure 3, the fluorescence peak of L-Cys-TAEA modified QDs exhibited a slightly red-shifted emission as compared to that of corresponding QDs, indicating that the emission arises due to the recombination of L-Cys-TAEA-5-FUA on the surface of QDs.

\section{Cytotoxicity of QDs}

The cytotoxicity of original and modified QDs was investigated in HeLa, SMMC-7721, QSG-7701, and HepG2 cells using the MTT assay. Calculated $\mathrm{IC}_{50}$ values of original and modified QDs are shown in Table 1. The result demonstrated that original QDs are highly toxic towards both tumor cells and normal cells. It indicates that there is no obvious selectivity for normal cells and cancer cells. Notably, all the L-Cys-TAEA-5-FUA modified QDs exerted less toxicity on the normal liver QSG7701 cells as compared to the three types of cancer cells. Interestingly, the CdSe/ZnS@L-Cys-TAEA-5-FUA QDs have better anti-tumor activity in comparison with 5-FUA. Therefore, it is easy to understand that $\mathrm{CdSe} /$ ZnS@L-Cys-TAEA-5-FUA QDs possess obvious selectivity for normal cells and cancer cells. Henceforth,

Table I IC 50 Values of Modified and Unmodified QDs

\begin{tabular}{|c|c|c|c|c|}
\hline \multirow[t]{2}{*}{ Compounds } & \multicolumn{4}{|c|}{$I C_{50}(\mu \mathrm{g} / \mathrm{mL})$} \\
\hline & HeLa & $\begin{array}{l}\text { SMMC- } \\
7721\end{array}$ & HepG2 & $\begin{array}{l}\text { QSG- } \\
7701\end{array}$ \\
\hline CdSe@L-Cys-TAEA & $389.5 \pm 3.5$ & $425.6 \pm 4.5$ & $434.8 \pm 3.9$ & $463.7 \pm 2.9$ \\
\hline $\begin{array}{l}\text { CdSe/ZnS@L-Cys- } \\
\text { TAEA }\end{array}$ & $329.4 \pm 3.8$ & $400.0 \pm 4.7$ & $413.6 \pm 4.6$ & $439.5 \pm 3.6$ \\
\hline $\begin{array}{l}\text { CdSe/CdS@L-Cys- } \\
\text { TAEA }\end{array}$ & $339.1 \pm 3.7$ & $4 \mid 2.6 \pm 4.3$ & $432.3 \pm 4.9$ & $457.9 \pm 2.7$ \\
\hline $\begin{array}{l}\text { CdSe@L-Cys-TAEA } \\
\text {-5-FUA }\end{array}$ & $46.3 \pm 1.8$ & $60.8 \pm 2.9$ & $61.2 \pm 2.1$ & $80.0 \pm 3.2$ \\
\hline $\begin{array}{l}\text { CdSe/ZnS@L-Cys- } \\
\text { TAEA-5-FUA }\end{array}$ & $41.8 \pm 3.2$ & $49.9 \pm 2.3$ & $50.7 \pm 3.1$ & $106.5 \pm 2.3$ \\
\hline $\begin{array}{l}\text { CdSe/CdS@L-Cys- } \\
\text { TAEA-5-FUA }\end{array}$ & $44.2 \pm 40.3$ & $56.7 \pm 1.7$ & $55.8 \pm 3.4$ & $97.6 \pm 2.1$ \\
\hline 5-FUA & $71.1 \pm 2.6$ & $68.3 \pm 3.1$ & $61.4 \pm 2.7$ & $69.4 \pm 2.9$ \\
\hline $\mathrm{CdSe}$ & $17.5 \pm 2.5$ & $13.9 \pm 3.1$ & $14.5 \pm 3.4$ & $16.7 \pm 3.1$ \\
\hline $\mathrm{CdSe} / \mathrm{ZnS}$ & $15.4 \pm 2.2$ & $13.2 \pm 1.9$ & $13.7 \pm 2.9$ & $14.5 \pm 2.4$ \\
\hline $\mathrm{CdSe} / \mathrm{CdS}$ & $16.2 \pm 3.1$ & $14.4 \pm 2.7$ & $13.8 \pm 2.8$ & $15.4 \pm 1.7$ \\
\hline
\end{tabular}


CdSe/ZnS@L-Cys-TAEA-5-FUA QDs were used as a representative QDs for the subsequent experiments. At the same time, the cytotoxicity of L-Cys-TAEA modified QDs was found to be lower for normal cells and cancer cells. Overall, the cytotoxicity study revealed that the L-Cys-TAEA-5-FUA modified QDs can inhibit the proliferation of tumor cells effectively while showing less cytotoxicity towards normal cells.

\section{Effect of Different Concentrations of Modified QDs on Cell Morphology}

The analysis of morphology of HeLa cells in response to different concentrations of $\mathrm{CdSe} / \mathrm{ZnS} @$ L-Cys-TAEA -5-FUA QDs was carried out by Hoechst 33342 staining using a fluorescence microscope. Figure 4 shows the changes of distribution and cell morphology in presence of CdSe/ZnS@L-Cys-TAEA-5-FUA QDs at different concentrations $(20 \mu \mathrm{g} / \mathrm{mL}$ : Figure $4 \mathrm{~A}, 50 \mu \mathrm{g} / \mathrm{mL}$ : Figure 4B, $100 \mu \mathrm{g} / \mathrm{mL}$ : Figure 4C, and $200 \mu \mathrm{g} / \mathrm{mL}$ : Figure 4D). Upon internalization, the modified QDs remained intact in cells with a distribution in a cytoplasm. The results also exhibited that the modified QDs treatment could increase the number of apoptotic nucleus in HeLa cells in a concentration-dependent manner and these cells showed typical apoptotic changes, including stained brightness, reduction of cellular volume, fragmented nuclei, as well as condensed chromatin. However, no obvious apoptosis phenomenon was observed in QSG-7701 cells in presence of CdSe/ZnS@L-Cys-TAEA-5-FUA. These results indicate that modified QDs possess certain selectivity towards tumor cells and can inhibit their proliferation effectively by inducing early apoptosis.
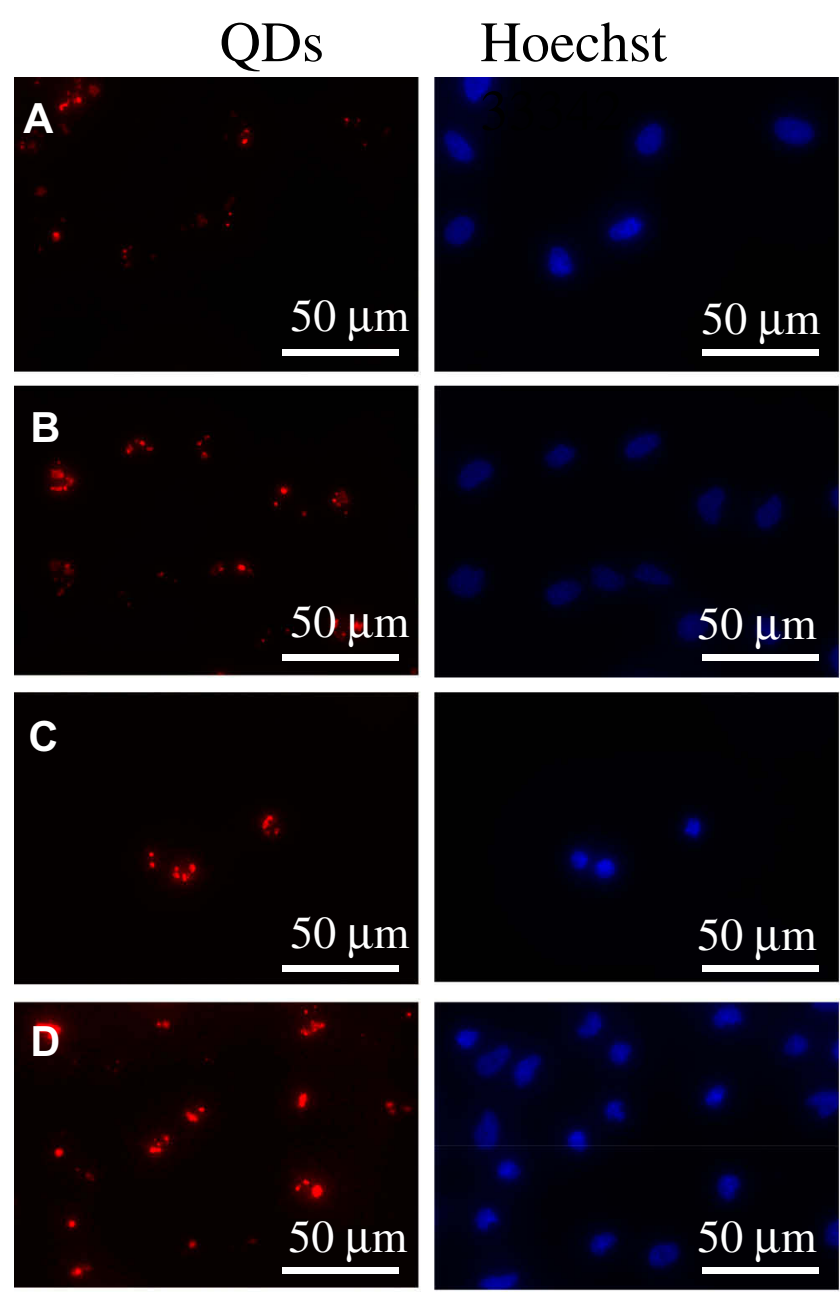
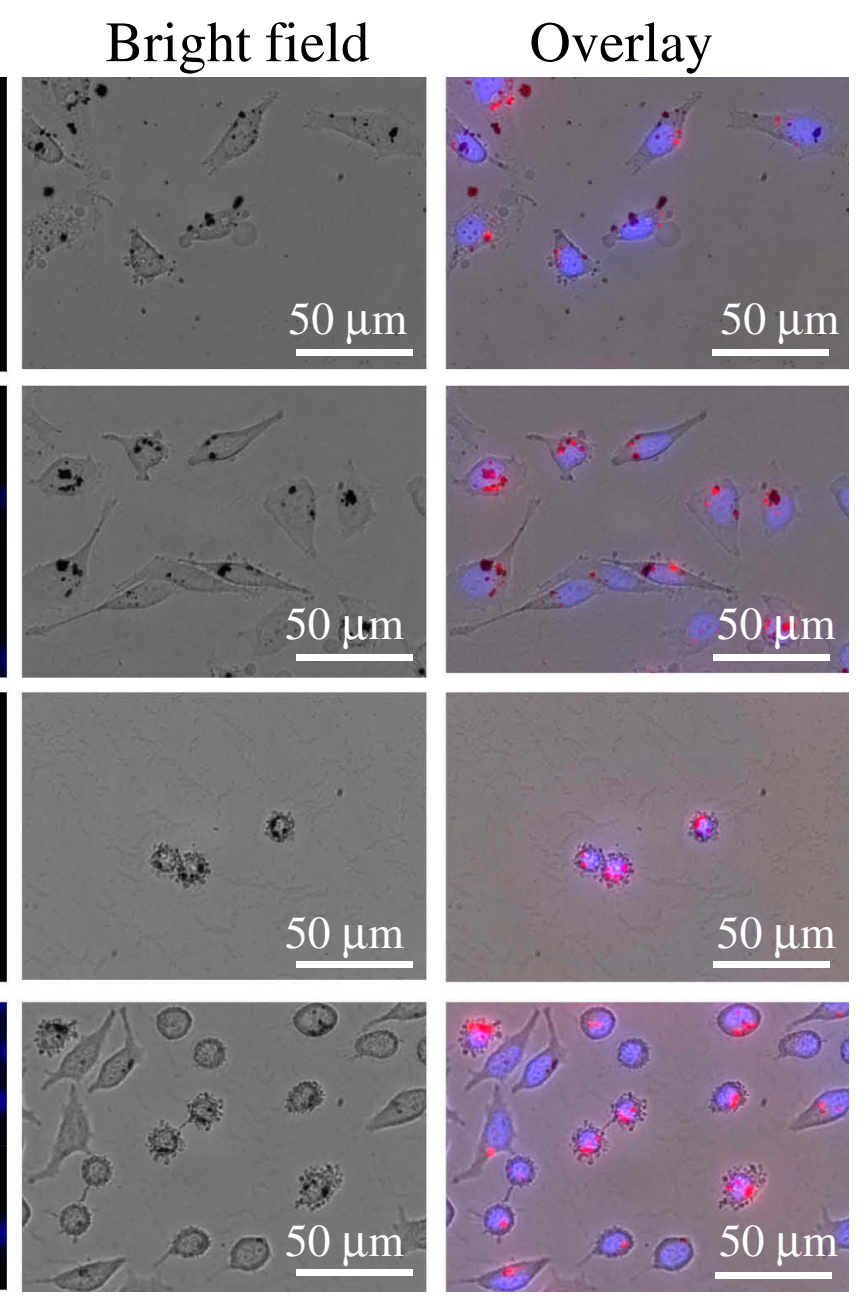

Figure 4 The distribution and cell morphology in HeLa cells in response to the treatment of CdSe/ZnS@L-Cys-TAEA-5-FUA QDs at different concentrations. (A) 20 $\mu$ g/ $\mathrm{mL}$, (B) $50 \mu \mathrm{g} / \mathrm{mL}$, (C) $100 \mu \mathrm{g} / \mathrm{mL}$, and (D) $200 \mu \mathrm{g} / \mathrm{mL}$. Scale bars $=50 \mu \mathrm{m}$. 
A
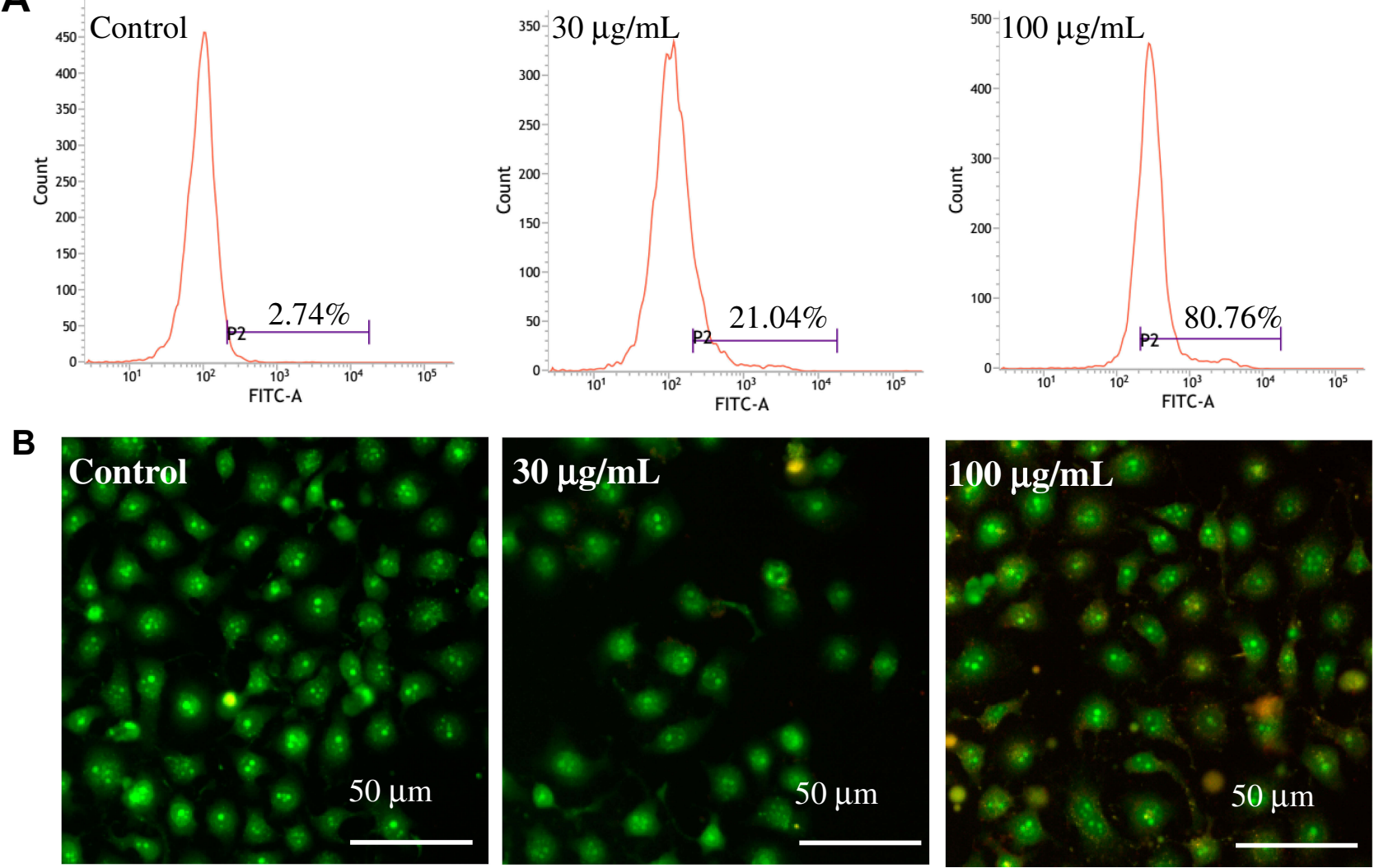

Figure 5 Apoptosis analysis in HeLa cells treated with CdSe/ZnS@L-Cys-TAEA-5-FUA (30 $\mu \mathrm{g} / \mathrm{mL}$ and I00 $\mu \mathrm{g} / \mathrm{mL})$ using (A) flow cytometry data (Annexin V-FITC staining) and (B) fluorescence microscope images (AO/EB staining) of HeLa, Scale bars $=50 \mu \mathrm{m}$.

\section{Induction of Apoptosis}

To confirm the early apoptosis in HeLa cells in presence of CdSe/ZnS@L-Cys-TAEA-5-FUA QDs, apoptosis assay was carried out by flow cytometry using Annexin V-FITC kit. As shown in Figure 5A, the percentage of early apoptotic cells was significantly higher in response to the modified QDs treatment (30 $\mu \mathrm{g} / \mathrm{mL}: 21.04 \%$ and 100 $\mu \mathrm{g} / \mathrm{mL}: 80.76 \%$ ) as compared to the control experiment (2.74\%). In addition, the cell apoptosis was further studied through fluorescence microscopy using AO/EB staining. As can be seen from Figure 5B, the control cells were found to be structurally intact and green fluorescence was observed in cell nucleus due to the passing of AO through the intact cell membrane. Contrastingly, the cells treated with the modified QDs exhibited orange fluorescence as the EB passed through the damaged cell membrane. Furthermore, the orange fluorescence intensity in cells was gradually increased with increasing concentration of the modified QDs. Overall, these results revealed that the modified QDs can induce apoptosis in cancer cells in a concentration-dependent manner.

\section{The Reduction of Mitochondrial Membrane Potential (MMP)}

To examine CdSe/ZnS@L-Cys-TAEA-5-FUA mediated potential mitochondrial dysfunctions in HeLa cells, fluorescence microscopy was employed using JC-1 dye staining. The dye molecules are separate at low concentration and can emit green fluorescence (monomeric form), but form J-aggregates with red-shift emission. Figure 6A presents the quantitative analysis results of JC-1-stained HeLa cells employing flow cytometry. The result exhibited significant increase of red/green ratio in modified QDs-treated cells as compared to that of control cells, suggesting that modified QDs are capable of inducing apoptosis.

Additionally, the MMP of HeLa cells in presence of the modified QDs was further checked employing fluorescence microscope using the Rhodamine 123/Hoechst 33342 staining. The structurally intact control cells exhibited intense green fluorescence (Figure 6B). However, the intensity of green fluorescence was decreased in cells in the presence of modified QDs in a dose-dependent manner, indicating mitochondrial membrane damage. Altogether, 
A

Control

$30 \mu \mathrm{g} / \mathrm{mL}$

$50 \mu \mathrm{g} / \mathrm{mL}$

$100 \mu \mathrm{g} / \mathrm{mL}$
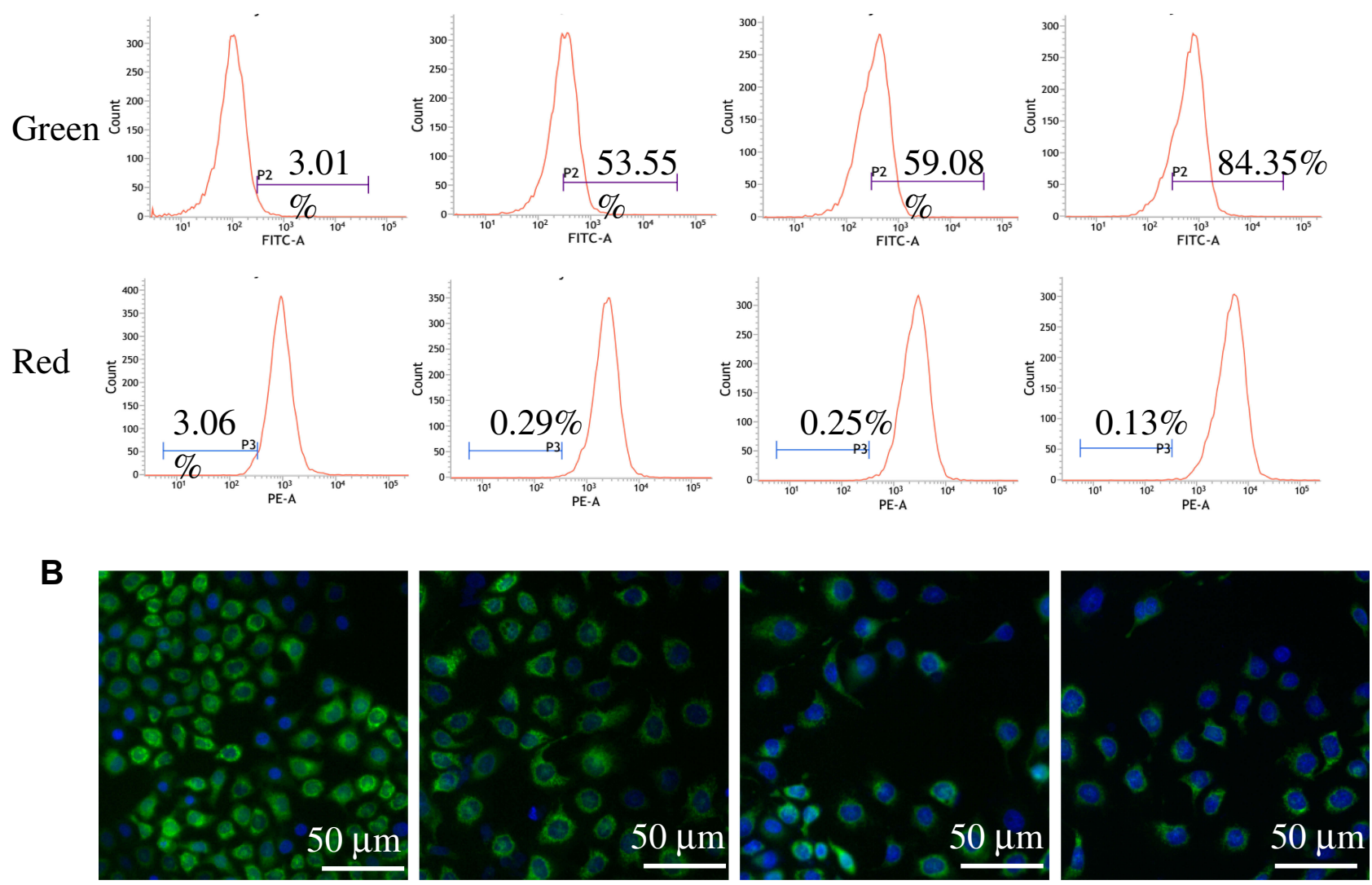

Figure 6 Effects of QDs on MMP of HeLa cells. (A) Flow cytometry images (JC-I staining) and (B) fluorescence microscopy images (Rhodamine 123 staining).

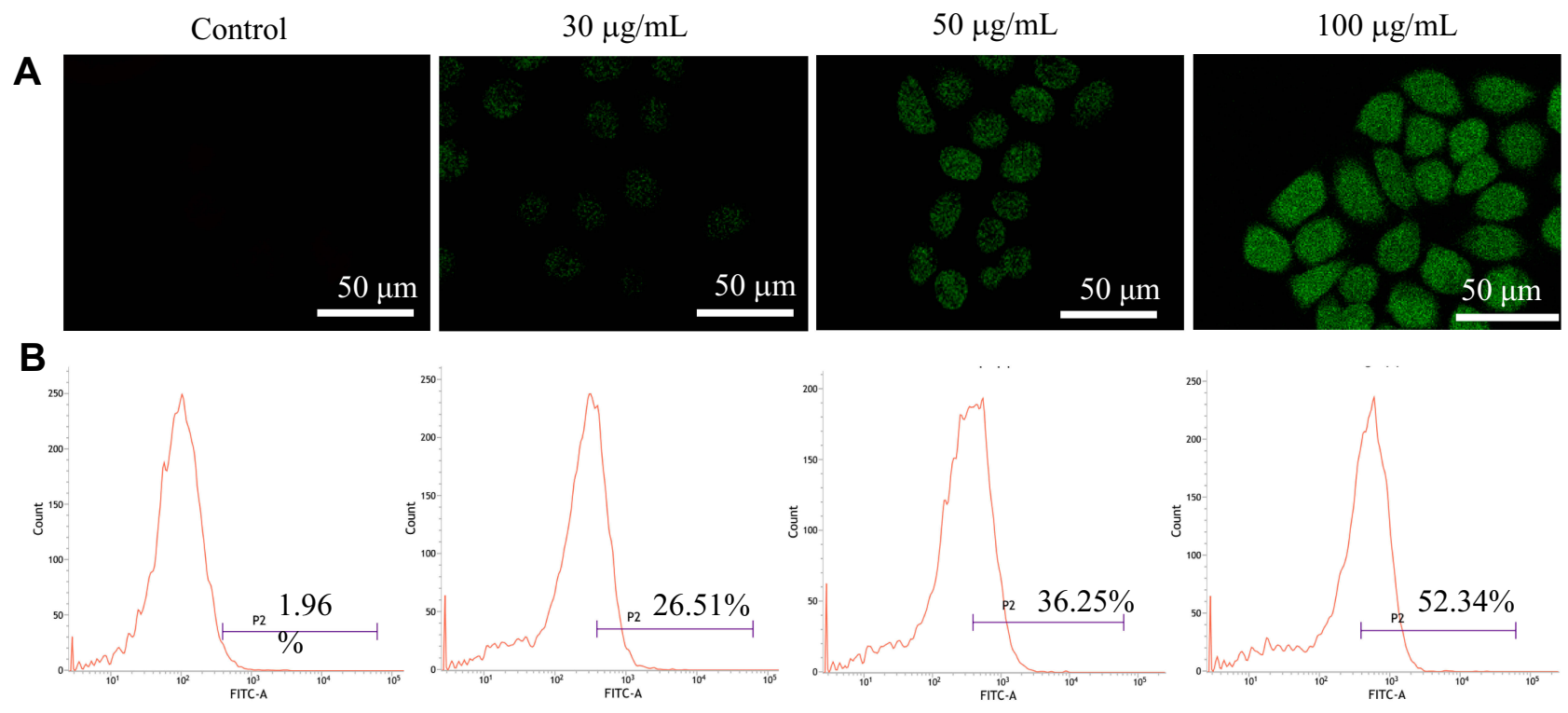

Figure 7 The determination of intracellular level of ROS in HeLa cells using $\mathrm{H}_{2}$ DCF-DA reagent through (A) fluorescence microscope and (B) flow cytometry. 
the results suggest that the modified QDs could induce apoptosis in HeLa cells through depolarization of MMP.

\section{Determination of ROS Generation in HeLa Cells Treated with Modified QDs}

To investigate whether the mitochondrial membrane damage in HeLa cells in the presence of the modified QDs was mediated by the excessive intracellular ROS generation, fluorescence microscopy, and flow cytometry were employed using $\mathrm{H}_{2}$ DCF-DA reagent. As shown in Figure 7A, the intensity of green fluorescence $\left(\mathrm{H}_{2} \mathrm{DCF}-\mathrm{DA}\right.$ staining) in modified QDs-treated cells was significantly higher as compared to the control experiment, indicating that QDs could induce the excessive formation of ROS inside cells. The flow cytometry experiment further confirmed that the intracellular ROS level was significantly increased in cells treated with the modified QDs in a dose-dependent manner as compared to the control cells (Figure 7B). These results depict that the modified QDs mediated mitochondrial dysfunction was likely due to the production of excessive intracellular ROS, leading to apoptosis process.

\section{Conclusions}

In conclusion, a new type of L-Cys-TAEA-5-FUA modified QDs was synthesized. The modified QDs exhibited improved water solubility and dispersibility. Moreover, the modified QDs exerted efficient inhibition of cancer cell proliferation as compared to the normal cells, indicating their antitumor activity. Post cellular internalization, the modified QDs could enter intracellular and they could effectively induce the formation of excessive intracellular ROS in cancer cells, leading to initiate the apoptosis process. The present study depicts that the modified QDs could be used as potent therapeutic agents to treat different types of cancers with fluorescent imaging.

\section{Acknowledgment}

This work was supported by National Natural Science Foundation of China (21501044), Program for Innovative Research Talents from the University of Henan Province (18HASTIT049), Foundation of Science and Technology Department of Henan Province (182102410075), Major cultivation project of First-class discipline of Henan University (2019YLZDJL09), and Special Professor project of Henan University.

\section{Author Contributions}

All authors contributed to data analysis, drafting or revising the article, gave final approval of the version to be published, and agree to be accountable for all aspects of the work.

\section{Disclosure}

The authors report no conflicts of interest in this work.

\section{References}

1. Ren DH, Wang B, Hu C, You Z. Quantum dot probes for cellular analysis. Anal Methods. 2017;9(18):2621-2632. doi:10.1039/C7A Y00018A

2. Rosenthal SJ, Chang JC, Kovtun O, McBride JR, Tomlinson ID Biocompatible quantum dots for biological applications. Chem Biol. 2011;18(1):10-24. doi:10.1016/j.chembiol.2010.11.013

3. Xia Y, Wang J, Zhang Y, et al. Quantum dot based turn-on fluorescent probes for anion sensing. Nanoscale. 2012;4(19):5954-5959. doi:10.10 39/c2nr31809a

4. Zhao M-X, Zeng E-Z, Zhu B-J. The biological applications of inorganic nanoparticle drug carriers. ChemNanoMat. 2015;1(2):82-91. doi:10.1002/cnma.201500036

5. Zhao M-X, Zeng E-Z. Application of functional quantum dot nanoparticles as fluorescence probes in cell labeling and tumor diagnostic imaging. Nanoscale Res Lett. 2015;10(1):171. doi:10.1186/s11671015-0873-8

6. Erathodiyil N, Ying JY. Functionalization of inorganic nanoparticles for bioimaging applications. Acc Chem Res. 2011;44(10):925-935. doi: $10.1021 /$ ar2000327

7. Zhao M-X, Zhu B-J, Yao W-J, Chen D-F, Wang C. The delivery of doxorubicin of multifunctional $\beta$-cyclodextrin-modified $\mathrm{CdSe} / \mathrm{ZnS}$ quantum dots for bioactivity and nano-probing. Chem Biol Drug Des. 2018;91(1):285-293. doi:10.1111/cbdd.13080

8. Zhang MY, Bishop BP, Thompson NL, et al. Quantum dot cellular uptake and toxicity in the developing brain: implications for use as imaging probes. Nanoscale Adv. 2019;1(9):3424-3442. doi:10.1039/ C9NA00334G

9. Fontana JM, Yin HJ, Chen Y, Florez R, Brismar H, Fu Y. Transport and release of colloidal 3-mercaptopropionic acid-coated CdSe-CdS/ $\mathrm{ZnS}$ core-multishell quantum dots in human umbilical vein endothelial cells. Int J Nanomedicine. 2017;12:8615-8629. doi:10.2147/IJN. S145608

10. Sur VP, Kominkova M, Buchtova Z, Dolezelikova K, Zitka O, Moulick A. CdSe QD biosynthesis in yeast using tryptone-enriched media and their conjugation with a peptide hecate for bacterial detection and killing. Nanomaterials. 2019;9(10):E1463. doi:10.3390/nano9101463

11. Lei Y, Tang H, Feng M, Zou B. Applications of fluorescent quantum dots to stem cell tracing in vivo. J Nanosci Nanotechnol. 2009;9 (10):5726-5730. doi:10.1166/jnn.2009.1258

12. Suzuki M, Udaka H, Fukuda T. Quantum dot-linked immunosorbent assay (QLISA) using orientation-directed antibodies. J Pharm Biomed Anal. 2017;143:110-115. doi:10.1016/j.jpba.2017.05.014

13. Rhyner MN, Smith AM, Gao XH, Mao H, Yang LL, Nie SM. Quantum dots and multifunctional nanoparticles: new contrast agents for tumor imaging. Nanomedicine. 2006;1(2):209-217. doi:10.2217/ 17435889.1.2.209

14. Huang T, Meng Q, Jie G. Silver nanowires-based signal amplification for CdSe quantum dots electrochemiluminescence immunoassay. Biosens Bioelectron. 2015;66:84-88. doi:10.1016/j.bios.2014.11.011

15. Lv YB, Wu RL, Feng KR, et al. Highly sensitive and accurate detection of C-reactive protein by $\mathrm{CdSe} / \mathrm{ZnS}$ quantum dot-based fluorescence-linked immunosorbent assay. J Nanobiotechnology. 2017;15(1):35. doi:10.1186/s12951-017-0267-4 
16. Barrett PJ, Song Y, Van Horn WD, et al. The amyloid precursor protein has a flexible transmembrane domain and binds cholesterol. Science. 2012;336(6085):1168-1171. doi:10.1126/science.1219988

17. Wu GY. Amino acids: metabolism, functions, and nutrition. Amino Acids. 2009;37(1):1-17. doi:10.1007/s00726-009-0269-0

18. Gao F, Ma S, Xiao X, Hu Y, Zhao D, He Z. Sensing tyrosine enantiomers by using chiral $\mathrm{CdSe} / \mathrm{CdS}$ quantum dots capped with N-acetyl-1-cysteine. Talanta. 2017;163:102-110. doi:10.1016/j. talanta.2016.10.091

19. Zhao M-X, Li Y, Zeng E-Z, Wang C. The application of CdSe quantum dots with multicolor emission as fluorescent probes for cell labeling. Chem Asian J. 2014;9(5):1349-1355. doi:10.1002/asia.201301692

20. Puri M, Ferry VE. Circular dichroism of CdSe nanocrystals bound by chiral carboxylic acids. ACS Nano. 2017;11(12):12240-12246. doi:10.1021/acsnano.7b05690

21. Xu DW, Zou W, Du ZJ, Wang H, Liu B, Zhang C. Novel synthesis of CdSe quantum dots in a confined space by using a high internal phase emulsion and their application in fluorescent labeling. ChemistrySelect. 2019;4(4):1456-1462. doi:10.1002/slct.201803228

22. Gomes D, Algarra M, Diez de Los Rios MJ, et al. CdSe and ZnSe quantum dots capped with PEA for screening C-reactive protein in human serum. Talanta. 2012;93:411-414. doi:10.1016/j.talanta.2012. 01.042

23. Tan L, Ge J, Jiao M, Jie G, Niu S. Amplified electrochemiluminescence detection of DNA based on novel quantum dots signal probe by multiple cycling amplification strategy. Talanta. 2018;183:108-113. doi:10.1016/j.talanta.2018.02.063

24. Brooks J, Lefebvre DD. Optimization of conditions for cadmium selenide quantum dot biosynthesis in Saccharomyces cerevisiae. Appl Microbiol Biotechnol. 2017;101(7):2735-2745. doi:10.1007/ s00253-016-8056-9

25. Valeriote F, Santelli G. 5-Fluorouracil (FURA). Pharm Ther. 1984;24 (1):107-132. doi:10.1016/0163-7258(84)90030-5

26. Bian Z, Jin L, Zhang J, et al. LncRNA-UCA1 enhances cell proliferation and 5-fluorouracil resistance in colorectal cancer by inhibiting miR-204-5p. Sci Rep. 2016;6:23892. doi:10.1038/srep23892

27. Vincent J, Mignot G, Chalmin F, et al. 5-Fluorouracil selectively kills tumor-associated myeloid-derived suppressor cells resulting in enhanced $\mathrm{T}$ cell-dependent antitumor immunity. Cancer Res. 2010;70(8):3052-3561. doi:10.1158/0008-5472.CAN-09-3690

28. Wyatt MD, Wilson DM. Participation of DNA repair in the response to 5-fluorouracil. Cell Mol Life Sci. 2009;66(5):788-799. doi:10.1007/s00018-008-8557-5

29. Kaplan AS, Ben-Porat T. The action of 5-fluorouracil on the nucleic acid metabolism of pseudorabies virus-infected and noninfected rabbit kidney cells. Virology. 1961;13(1):78-92. doi:10.1016/00426822(61)90034-4

30. Yang Z, Cloud A, Hughes D, Johnson LF. Stable inhibition of human thymidylate synthase expression following retroviral introduction of an siRNA gene. Cancer Gene Ther. 2006;13(1):107-114. doi:10.1038/sj.cgt.7700880

31. Farhat A, Malecki E, Bonaterra GA, et al. Cytostatic/cytotoxic effects of 5-fluorouridine nucleolipids on colon, hepatocellular, and renal carcinoma cells: in vitro identification of a potential cytotoxic multi-anticancer drug. Chem Biodivers. 2014;11(3):469-482. doi:10.1002/cbdv.201300347

International Journal of Nanomedicine

\section{Publish your work in this journal}

The International Journal of Nanomedicine is an international, peerreviewed journal focusing on the application of nanotechnology in diagnostics, therapeutics, and drug delivery systems throughout the biomedical field. This journal is indexed on PubMed Central, MedLine, CAS, SciSearch ${ }^{\mathbb{R}}$, Current Contents ${ }^{\mathbb{R}} /$ Clinical Medicine, $^{2}$
32. Agudo R, Arias A, Pariente N, et al. Molecular characterization of a dual inhibitory and mutagenic activity of 5-fluorouridine triphosphate on viral RNA synthesis. Implications for lethal mutagenesis. J Mol Biol. 2008;382(3):652-666. doi:10.1016/j.jmb.2008.07.033

33. Silverstein RA, González de Valdivia E, Visa N. The incorporation of 5-fluorouracil into RNA affects the ribonucleolytic activity of the exosome subunit Rrp6. Mol Cancer Res. 2011;9(3):332-340. doi:10.1158/1541-7786.MCR-10-0084

34. Yang S, Peng L-Y, Peng W, et al. Anticancer potentials of sinomenine from Sinomenium acutum: a mini-review. Trop $J$ Pharm Res. 2018;17(12):2519-2526. doi:10.4314/tjpr.v17i12.30

35. Liu LL, Wang D, Qiu Y, Dong HY, Zhan XM. Overexpression of microRNA-15 increases the chemosensitivity of colon cancer cells to 5-fluorouracil and oxaliplatin by inhibiting the nuclear factor-kappa B signalling pathway and inducing apoptosis. Exp Ther Med. 2018;15 (3):2655-2660.

36. Ooyama A, Takechi T, Toda E, et al. Gene expression analysis using human cancer xenografts to identify novel predictive marker genes for the efficacy of 5-fluorouracil-based drugs. Cancer Sci. 2006;97 (6):510-522. doi:10.1111/j.1349-7006.2006.00204.x

37. Prisciandaro LD, Geier MS, Butler RN, Cummins AG, Howarth GS. Probiotic factors partially improve parameters of 5-fluorouracilinduced intestinal mucositis in rats. Cancer Biol Ther. 2011;11 (7):671-677. doi:10.4161/cbt.11.7.14896

38. Fukudome I, Kobayashi M, Dabanaka K, et al. Diamine oxidase as a marker of intestinal mucosal injury and the effect of soluble dietary fiber on gastrointestinal tract toxicity after intravenous 5 -fluorouracil treatment in rats. Med Mol Morphol. 2014;47(2):100-107. doi:10.1007/s00795-013-0055-7

39. Iwasaki J, Nihira S. Anti-angiogenic therapy against gastrointestinal tract cancers. Jpan J Clin Oncol. 2009;39(9):543-551. doi:10.1093/ jjco/hyp062

40. Xu N, Piao M, Arkin K, et al. Imaging of water soluble CdTe/CdS core-shell quantum dots in inhibiting multidrug resistance of cancer cells. Talanta. 2019;201:309-316. doi:10.1016/j.talanta.2019.04.021

41. Bwatanglang IB, Mohammad F, Yusof NA, et al. In vivo tumor targeting and anti-tumor effects of 5-fluorouracil loaded, folic acid targeted quantum dot system. $J$ Colloid Interface Sci. 2016;480:146-158. doi:10.1016/j.jcis.2016.07.011

42. Shi XX, He DX, Tang GT, et al. Fabrication and characterization of a folic acid-bound 5-fluorouracil loaded quantum dot system for hepatocellular carcinoma targeted therapy. RSC Adv. 2018;8 (35):19868-19878. doi:10.1039/C8RA01025K

43. Li J, Wang Y, Zhu Y, Oupický D. Recent advances in delivery of drug-nucleic acid combinations for cancer treatment. $J$ Control Release. 2013;172(2):589-600. doi:10.1016/j.jconrel.2013.04.010

44. Zhu D, Chen Y, Jiang L, Geng J, Zhang J, Zhu JJ. Manganese-doped $\mathrm{ZnSe}$ quantum dots as a probe for time-resolved fluorescence detection of 5-fluorouracil. Anal Chem. 2011;83(23):9076-9081. doi:10.1021/ac202101u

45. Zhao M-X, Zeng E-Z, Li Y, Wang C-J. A study on effects of naphthalimide derivative-capped quantum dots on the cellular internalization, proliferation, and apoptosis ability. $J$ Mater Chem $B$. 2014;2(42):7351-7359. doi:10.1039/C4TB01048E

Journal Citation Reports/Science Edition, EMBase, Scopus and the Elsevier Bibliographic databases. The manuscript management system is completely online and includes a very quick and fair peer-review system, which is all easy to use. Visit http://www.dovepress.com/ testimonials.php to read real quotes from published authors. 